ISSN 1029-8940 (Print)

ISSN 2524-230X (Online)

УДК 581.95:581.526.32:502.72(476.1)

https://doi.org/10.29235/1029-8940-2018-63-4-437-446

Поступила в редакцию 10.01.2018

Received 10.01.2018

\author{
К. Л. Савицкая ${ }^{1}$ М. А. Джус ${ }^{2}$ \\ ${ }^{1}$ Институт экспериментальной ботаники им. В. Ф. Купревича, Минск, Республика Беларусь \\ ${ }^{2}$ Белорусский государственный университет, Минск, Республика Беларусь

\section{НОВЫЕ МЕСТОНАХОЖДЕНИЯ РЕДКИХ И ОХРАНЯЕМЫХ ВИДОВ РАСТЕНИЙ ВОДНЫХ ЭКОСИСТЕМ МИНСКОЙ ОБЛАСТИ И НАЦИОНАЛЬНОГО ПАРКА «БЕЛОВЕЖСКАЯ ПУЩА»}

\begin{abstract}
Аннотация. В результате флористических исследований водных объектов Минской области и Национального парка «Беловежская пуща» обнаружено 75 новых местонахождений 20 видов (1 гибрида) редких водных и заходящих в воду береговых растений. Из них 7 видов включены в основной список Красной книги Республики Беларусь, 5 видов взяты под профилактическую охрану. Для Беловежской пущи Potamogeton berchtoldii Fieber, Utricularia minor L., Potamogeton acutifolius Link, P. nodosus Poir., Salvinia natans (L.) All. приводятся впервые. Подробно рассмотрено распространение Berula erecta (Huds.) Coville в границах Национального парка. На территории Минской области описаны локалитеты Nuphar pumila (Timm) DC., Ranunculus kauffmannii Clerc., Najas major All., Berula erecta, Glyceria lithuanica (Gorski) Gorski, Conioselinum tataricum Hoffm., не вошедшие в 4-е издание Красной книги. Для выявленных видов водных растений дана краткая характеристика условий мест произрастания, а также указана их фитоценотическая приуроченность. Новые данные о местонахождениях охраняемых видов водных растений могут быть использованы для организации мониторинга их популяций, составления охранных паспортов и охранных обязательств.
\end{abstract}

Ключевые слова: водные растения, флора, новые местонахождения, редкие и охраняемые растения, Беловежская пуща, Минская область

Для цитирования: Савицкая, К. Л. Новые местонахождения редких и охраняемых видов растений водных экосистем Минской области и Национального парка «Беловежская пуща» / К. Л. Савицкая, М. А. Джус // Вес. Нац. акад. навук Беларусі. Сер. біял. навук. - 2018. - Т. 63, № 4. - С. 437-446. https://doi.org/10.29235/1029-8940-2018-63-4-437-446

\author{
K. L. Savitskaya ${ }^{1}$, M. A. Dzhus ${ }^{2}$ \\ ${ }^{I}$ V. F. Kuprevich Institute of Experimental Botany, Minsk, Republic of Belarus \\ ${ }^{2}$ Belarusian State University, Minsk, Republic of Belarus
}

\title{
NEW LOCATIONS OF RARE AND PROTECTED PLANT SPECIES OF THE AQUATIC ECOSYSTEMS OF MINSK REGION AND NATIONAL PARK "BELOVEZHSKAYA PUSHCHA"
}

Abstract. There is a review of floral studies of the water bodies in Minsk Region and National Park "Belovezhskaya Pushcha". 75 new locations of 20 rare aquatic and riverside plant species coming at the water and 1 hybrid were found. 7 of these species are listed in the Red Book of the Republic of Belarus, 5 species are included into the category of Least Concern and Data Deficient. Potamogeton berchtoldii Fieber, Utricularia minor L., Potamogeton acutifolius Link, P. nodosus Poir., Salvinia natans (L.) All. are reported for the first time from National Park «Belovezhskaya Pushcha». The spreading of Berula erecta (Huds.) Coville on the territory of National Park is considered in detail. New locations of Nuphar pumila (Timm) DC., Ranunculus kauffmannii Clerc., Najas major All., Berula erecta, Glyceria lithuanica (Gorski) Gorski, Conioselinum tataricum Hoffm. in Minsk Region, which were not included in 4th edition of the Red Book, have been described. A brief description of habitat environmental conditions is given for the revealed species of aquatic plants, and their phytocoenotic confinement is also pointed out. New information on the locations of protected aquatic plant species should be used to monitor their populations and prepare the documents of protection.

Keywords: aquatic plants, flora, new locations, rare and protected plants, Belovezhskaya Pushcha, Minsk Region

For citation: Savitskaya K. L., Dzhus M. A. New locations of rare and protected plant species of the aquatic ecosystems of Minsk Region and National park "Belovezhskaya Pushcha". Vestsi Natsyyanal'nai akademii navuk Belarusi. Seryya biyalagichnych navuk = Proceedings of the National Academy of Sciences of Belarus. Biological series, 2018, vol. 63, no. 4, pp. 437446 (in Russian). https://doi.org/10.29235/1029-8940-2018-63-4-437-446

(C) Савицкая К. Л., Джус М. А., 2018 
Введение. На протяжении двух последних столетий изучению флоры водных объектов Минской области и Национального парка «Беловежская Пуща» уделялось наименьшее внимание по сравнению с другими типами природных экосистем. В то же время практическая значимость и актуальность флористических исследований акваторий и ветландов, отличающихся интразональными свойствами [1], постоянно возрастают в связи с увеличением степени антропогенной нагрузки на природные комплексы республики. При этом предпочтительно проводить единовременную (в течение одного вегетационного сезона) инвентаризацию водной флоры достаточно крупных регионов (например, нескольких административных районов или особо охраняемой природной территории). Это даст возможность адекватно оценить встречаемость того или иного вида и пропорции региональной флоры в целом, а повторные флористические учеты позволят четче выявить произошедшие изменения в структуре видового разнообразия.

Цель работы - изучение флоры водоемов и водотоков Минской области (2013-2017 гг.) и Национального парка «Беловежская пуща» (2017 г.) для уточнения распространения многих видов редких водных растений.

Материалы и методы исследования. Флористические исследования проводили маршрутным и детально-маршрутным методами. При описании фитоценозов водных объектов и гербаризации растений следовали стандартным гидроботаническим методикам $[2,3]$. Координаты пунктов сбора растений фиксировали с помощью GPS навигатора Garmin eTrex 10. Расположение видов в списке соответствовало системе Angiosperm Phylogeny Group, 2016 (APG IV) [4], номенклатура таксонов приведена по [5-9]. Использовали следующие обозначения скорости течения рек: малая (до 0,2 м/с), средняя (0,2-1 м/с), высокая (1-2 м/с). Сообщества классифицировали по методу Ж. Браун-Бланке, при этом учитывали данные современных синтаксономических обзоров по водной и прибрежно-водной растительности [10-14]. Наименования экологических групп растений приведены согласно представленным в работе [15]. Гербарные образцы переданы в Гербарий ИЭБ им. В. Ф. Купревича НАН Беларуси (MSK) и Гербарий Белорусского государственного университета (MSKU).

В работе приняты следующие сокращения: асс. - ассоциация, В - восток, вдхр. - водохранилище, в. д. - восточная долгота, г. - город, д. - деревня, 3 - запад, обл. - область, оз. - озеро, р. - река, p-н - район, C - север, с/с - сельсовет, с. ш. - северная широта, х. - хутор, экз. - экземпляр, Ю - Юг.

Результаты и их обсуждение. Ниже перечислены адреса местонахождений и иные сопутствующие сведения, касающиеся обнаруженных видов водных и заходящих в воду береговых сосудистых растений.

Семейство Сальвиниевые - Salviniaceae Martinov

\section{Salvinia natans (L.) All. - Сальвиния плавающая}

Брестская обл., Каменецкий р-н, 1 км к Ю-З от д. Шишово, правобережный бассейн р. Лесная, в канале на заболоченном торфянике. $52^{\circ} 26^{\prime} 46,05^{\prime \prime}$ с. ш., $23^{\circ} 51^{\prime} 55,87^{\prime \prime}$ в. д. К. Л. Савицкая (далее К. С.), И. М. Степанович (далее И. С.). 18.07.17. Нередко на площади 270 м². Глубина 1,6 м, грунт илисто-торфянистый, течение отсутствует, затенение до 30 \% (от Salix caprea L., S. cinerea L.). В составе фитоценоза асc. Lemno minoris-Ceratophylletum demersi (Hilbig, 1971) Pass., 1995, граничащего с ценозами асc. Phragmitetum communis Savich, 1926, acc. Typhetum angustifoliae Pignatti, 1953. Произрастает совместно с Lemna gibba L. и др.

Семейство Кувшинковые - Nymphaeaceae Salisb.

Nuphar pumila (Timm) DC. - Кубышка малая

Минская обл., Минский р-н, окрестности д. Юзуфово, пруд на р. Чернявка. 546'48,53" с. ш., $27^{\circ} 28^{\prime} 15,01^{\prime \prime}$ в. д. К. С. 25.06.16. Численность популяции 3 экз $/ \mathrm{m}^{2}$; площадь, занимаемая ценопопуляцией, $40 \mathrm{~m}^{2}$. Открытый участок малопроточного пруда с песчано-илистым грунтом, глубина 1,2 м. В полосе акватории, примыкающей к берегу. Сообщества с преобладанием Nuphar pumila (acc. Nupharetum pumilae Miljan, 1958) граничат с ценозами acc. Nymphaeetum candidae Miljan, 1958, acc. Equisetetum fluviatilis Nowiński, 1930, acc. Phragmitetum communis (Gams, 1927) Schmale, 1939.

Nymphaea $\times$ marliacea Lat.-Marl. (гибрид Nymphaea alba L. $\times$ Nymphaea mexicana Zucc. $\times$ Nymphaea odorata Aiton) - Кувшинка Марлиака 
Таксономический статус и происхождение культивируемых в Беларуси и странах Европы декоративных, гибридных кувшинок, окончательно не решен [16]. Предполагается, что в культуре наиболее распространена Nymphaea $\times$ marliacea [17], однако это требует специального изучения.

Минская обл., Минский р-н, 1 км к В от д. Ворошилы, пруд на реке, впадающей в вдхр. Крылово. К. С. 25.06.16. Единичные особи. Открытый прибрежный участок пруда, глубина 0,5 м, грунт песчаный, течение практически отсутствует.

Минская обл., Дзержинский р-н, мелководный водоем на С-В окраине г. Дзержинск. 27.07.2014. Писаненко А. Д.

Минская обл., Пуховичский р-н, г. Марьина Горка, пруд вблизи ул. Октябрьская. 28.08.2014. Бункевич Е. Ю. Заросли на площади $20 \times 40$ м.

Семейство Аронниковые - Araceae Juss.

Lemna turionifera Landolt - Ряска турионообразующая

В ходе исследований 2010-2011 гг., несмотря на специально предпринятые поиски, нам не удалось обнаружить этот высокоактивный вид на территории Национального парка, хотя он указывается для польской части Беловежской пущи [18]. За прошедшее с тех пор время распространение ряски турионообразующей, вероятно, значительно расширилось и регулярно фиксируется на белорусской территории парка с 2016 г.

Брестская обл., Пружанский р-н:

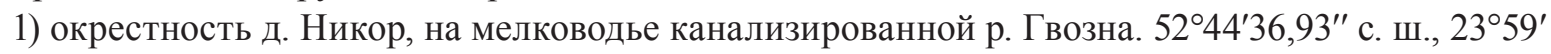
53,12" в. д. М. А. Джус (далее Д. М.). 27.04.2016. Изредка. Глубина 0,3 м, грунт илистый, затенение до 20 \%. В составе сообщества произрастает совместно с Lemna gibba L., L. minor L. и др.;

2) В окрестности д. Тарасы, р. Калиновец. Невыраженное русло реки в усыхающем заболоченном черноольшанике. $52^{\circ} 29^{\prime} 44,45^{\prime \prime}$ с. ш., $24^{\circ} 6^{\prime} 53,62^{\prime \prime}$ в. д. К. С., И. С. 19.07.17. Часто на площади

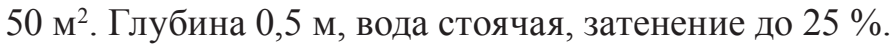

Брестская обл., Каменецкий р-н, 1 км к Ю-3 от д. Шишово, правобережный бассейн р. Лесная, канал на заболоченном торфянике. $52^{\circ} 26^{\prime} 46,05^{\prime \prime}$ с. ш., $23^{\circ} 51^{\prime} 55,87^{\prime \prime}$ в. д. К. С., И. С. 18.07.17. Часто


до $30 \%$ (наблюдение).

Распространение вида, отмеченное во втором томе «Флоры Беларуси», далеко не полное [19]. Ниже приводятся местонахождения только в тех административных районах, которые не указаны во «Флоре» для Минской области.


Д. М. 28.08.15.

Смолевичский р-н, окр. д. Шеметово, р. Уша. 5354'28,00" с. ш., 28¹'49,63" в. д. Д. М. 02.08.16.

Минский р-н, г. Минск:

1) у пересечения ул. Космонавтов и просп. Дзержинского, на мелководье р. Мухля. Д. М. 10.09.13;

2) вблизи ул. Шейпичи, р. Свислочь. Д. М. 11.09.13;

3) вблизи ул. Якубова, р. Свислочь. Д. М. 11.09.13;

4) д. Вишневка (Папернянский с/с), пруд на притоке р. Вяча. К. С. 25.06.16. Глубина 0,3 м, грунт илисто-песчаный.

В 2016 г. этот вид отмечен нами также для оз. Нарочь.

Червенский р-н, д. Рудня, р. Уша. К. С. 29.08.13. В акватории реки 200-250 м восточнее моста. Глубина 1,5 м, грунт илисто-песчаный, затенение $30 \%$.

Копыльский р-н, С окрестности д. Корзуны, мелиоративный канал. К. С. 28.07.14. Глубина 0,3 м, грунт илистый.

Столбцовский р-н, г. Столбцы, р. Неман. К. С. 27.07.14. Глубина 0,5 м, грунт песчаный, скорость течения средняя.

Несвижский р-н:

1) 1 км к Ю-В от д. Фольварковцы, мелиоративный канал. К. С. 26.07.14. Глубина 0,6 м, грунт илисто-торфянистый; 
2) 1 км к С-3 от д. Каролина, р. Уша (вблизи моста). К. С. 26.07.14. Глубина 0,75 м, грунт илисто-песчаный, течение медленное; 0,5 км к С-В от д. Студенки, р. Уша (вблизи моста). Глубина 0,65-1,5 м, грунт илисто-песчаный, течение медленное.

Крупский р-н:

1) д. Бобр, р. Бобр (вблизи моста). К. С. 19.07.14. Глубина 0,75 м, грунт песчаный, скорость течения средняя;

2) окрестность д. Новые Пышачи, р. Можа (вблизи моста). К. С. 19.07.14. Глубина 0,7 м, грунт песчаный, скорость течения средняя;

3) д. Прошика, р. Высокая (вблизи моста). К. С. 20.07.14. Глубина 1,15 м, грунт илисто-песчаный, течение медленное;

4) 3,5 км к В от д. Холопеничи, p. Эсса. К. С. 20.07.2014. Глубина 0,55 м, грунт илисто-песчаный, течение медленное.

Березинский р-н:

1) В окрестности д. Погост, р. Клевица. К. С. 23.07.14. Глубина 1 м, грунт илистый, течение медленное;

2) В окрестности д. Едлино, р. Березина. К. С. 23.07.14. Глубина 0,65 м, грунт илисто-песчаный, течение медленное.

Дзержинский р-н:

1) С окрестности д. Станьково, р. Уса. К. С. 07.07.15. Глубина 1,08 м, грунт песчаный, скорость течения средняя;

2) Ю окрестности д. Добринево, пруд на р. Жесть. К. С. 29.06.15. Глубина 0,8 м, грунт илистый;

3) 3 окрестности д. Кленовка, пруд на р. Рапусса. К. С. 29.06.15. Глубина 0,35 м, грунт илисто-песчаный.

Борисовский р-н:

1) Ю окрестности д. Клыпенка, р. Бобр. $54^{\circ} 06^{\prime} 44,8^{\prime \prime}$ с. ш., $28^{\circ} 52^{\prime} 59,7^{\prime \prime}$ в. д. К. С. 29.07.15. Глубина 0,6 м, грунт песчаный, скорость течения средняя;

2) д. Тарасовка, p. Сха. $54^{\circ} 17^{\prime} 18,4^{\prime \prime}$ с. ш., $28^{\circ} 32^{\prime} 22,1^{\prime \prime}$ в. д. К. С. 30.07 .15 . Глубина 0,6 м, грунт илисто-песчаный;

3) 3 окрестности д. Пересады, р. Плиса. $54^{\circ} 08^{\prime} 04,8^{\prime \prime}$ с. ш., $28^{\circ} 24^{\prime} 45,9^{\prime \prime}$ в. д. К. С. 29.07.15. Глубина 1 м, грунт песчаный, скорость течения средняя;


Глубина 0,5 м.

Клецкий р-н, 2,5 км к В от д. Звонка, вдхр. на р. Нача (вблизи территории оздоровительного лагеря). $52^{\circ} 55^{\prime} 01,0^{\prime \prime}$ с. ш., $26^{\circ} 31^{\prime} 01,1^{\prime \prime}$ в. д. К. С. 11.08.15. Глубина 0,8 м, грунт илисто-песчаный оторфованный.

Семейство Водокрасовые - Hydrocharitaceae Juss.

Najas major All. - Наяда большая

Минская обл., Мядельский р-н, 2,2 км к С-3 от г. п. Свирь, оз. Свирьнище. 54²52'23,2” с. ш., $26^{\circ} 22^{\prime} 33,2^{\prime \prime}$ в. д. К. С. 25.07.15. Численность популяции 3 экз $/ \mathrm{M}^{2}$; площадь, занимаемая метапопуляцией, 12 м². Глубина 1,4 м, грунт илисто-песчаный, открытый участок озера. В сообществе харовых водорослей.

Семейство Рдестовые - Potamogetonaceae Bercht. et J. Presl

Potamogeton acutifolius Link - Рдест остролистный

Гродненская обл., Свислочский р-н, 2,2 км к Ю от д. Лубянка, вдхр. Лубянское. 5247'47,40" с. ш., $24^{\circ} 34^{\prime} 13,23^{\prime \prime}$ в. д. К. С., И. С. 23.07.17. Глубина 1 м, грунт торфянисто-песчаный, затенение отсутствует. Отдельные растения и мелкие куртины. Редко.

\section{Potamogeton alpinus Balb. - Рдест альпийский}

Минская обл., Стародорожский р-н, 2 км к Ю-В от д. Залужье, р. Солон (вблизи моста). К. С. 03.07.13. Площадь ценопопуляции - 5 м² $^{2}$. Глубина 0,23 м, грунт илистый, течение медленное, затенение отсутствует. Образует фитоценозы acc. Elodeo-Potametum alpini (Podb., 1967) Pass., 1994. 


\section{Potamogeton berchtoldii Fieber - Рдест Берхтольда}

Гродненская обл., Свислочский р-н, 1,5 км к С-В от д. Залеский Бор, канал Залеский Бор

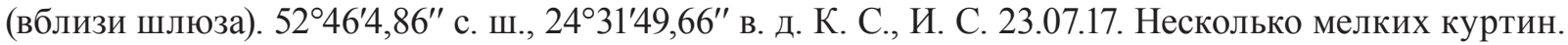
Редко. Глубина 0,1 м, течение медленное, грунт илисто-песчаный, затенение отсутствует.

Брестская обл., Пружанский р-н, В окрестности д. Тарасы, р. Калиновец. Невыраженное русло реки в усыхающем заболоченном черноольшанике. $52^{\circ} 29^{\prime} 44,45^{\prime \prime}$ с. ш., $24^{\circ} 6^{\prime} 53,62^{\prime \prime}$ в. д. К. С.,

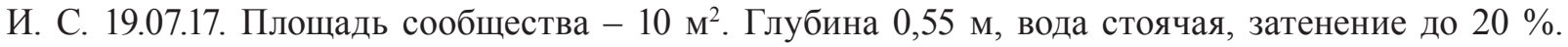
Произрастает совместно с плавающими на поверхности воды, неукореняющимися гидрофитами. Является доминантом сообщества, граничащего с ценозом асс. Typhetum latifoliae Nowiński, 1930.

Брестская обл., Каменецкий р-н:

1) 0,5 км к В от д. Панасюки, временный водоем в долине притока р. Белая (длительно зато-

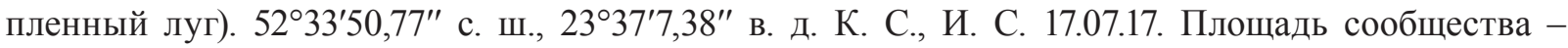

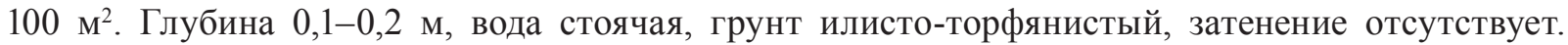
В малом обилии произрастает в составе сообществ асс. Lemnetum trisulcae den Hartog, 1963;

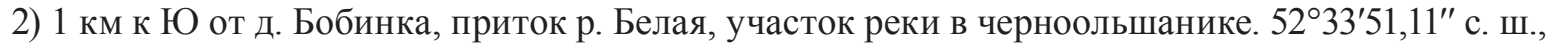
$23^{\circ} 33^{\prime} 19,88^{\prime \prime}$ в. д. К. С., И. С. 17.07.17. Группы из нескольких растений, редко, в сообществе асс. Lemno-Callitrichetum palusrtis A. Bobrov et Chemeris, 2006. Глубина 0,15 м, скорость течения средняя, грунт мелкопесчаный, затенение до $60 \%$.

Potamogeton nodosus Poir. - Рдест узловатый

Брестская обл., Каменецкий р-н, С окрестности д. Рожковка, пруд. 52³2'40,21" с. ш., $23^{\circ} 41^{\prime} 59,32^{\prime \prime}$ в. д. К. С., И. С. 17.07.17. Площадь сообщества - 15-60 м². Глубина 1,4 м, грунт илисто-песчаный, затенение отсутствует. Ценозы рдеста узловатого (acc. Potametum nodosi (Soó, 1960) Segal, 1964) граничат с сообществами acc. Potametum natantis Hild, 1959 и acc. Phragmitetum communis. В их состав также входят харовые водоросли, Myriophyllum spicatum L., Stuckenia pectinata (L.) Börner.

Минская обл., Столбцовский р-н, 1,3 км к 3 от д. Хутор-Борок, р. Сула. К. С. 27.07.14. Площадь сообщества (acc. Potametum nodosi) - 9 м². Глубина 0,55 м, грунт илисто-песчаный, скорость течения высокая, затенение $55 \%$.

Минская обл., Вилейский р-н, 0,7 км к С-3 от д. Сивцы, р. Узлянка. К. С. 14.07.13. Площадь

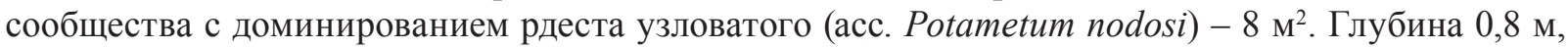
грунт илисто-песчаный, скорость течения средняя, затенение $65 \%$.

\section{Potamogeton trichoides Cham. et Schtdl. - Рдест волосовидный}

Минская обл., Борисовский р-н, д. Бояры, р. Болотница. К. С. 10.07.17. Единичные особи, редко. Глубина 0,7 м, грунт илистый, затенение отсутствует. В составе фитоценоза асс. Lemnetum trisulcae.

Минская обл., Копыльский р-н:

1) д. Колодезное, деревенская копань. К. С. 03.07.17. Мелкие куртины, нередко по всей акватории копани. Глубина 0,75 м, грунт илисто-песчаный, затенение отсутствует. В составе фитоценоза acc. Ceratophylletum demersi Corillion 1957;

2) д. Песочное, р. Неман. К. С. 03.07.17. Мелкие куртины, нередко по всей акватории реки на 200 -метровом участке. Глубина 1,2 м, грунт илисто-песчаный, затенение до $20 \%$. В составе фитоценоза acc. Lemno-Spirodeletum polyrhizae W. Koch, 1954 вместе с Lemna turionifera Myriophyllum sibiricum Kom., Potamogeton friesii Rupr. и др.

Минская обл., Столбцовский р-н, В окрестности д. Заречье, пруд на притоке р. Шура (участок пруда между двумя мостами). К. С. 15.08.15. Редко. Глубина 0,8 м, грунт илисто-песчаный, затенение отсутствует.

Минская обл., Пуховичский р-н, 1,1 км к С-В от д. Любячка, канал, впадающий в р. Талька. К. С. 01.08.16. Мелкие куртины, нередко по всей акватории канала на 200-метровом участке. Глубина 0,3 м, илисто-торфянистый грунт, затенение отсутствует.

Минская обл., Мядельский р-н, 1,5 км к Ю-В от д. Триданы, пруд на реке. К. С. 23.07.16. Единичные особи, редко. Глубина 0,65 м, илисто-торфянистый грунт, затенение отсутствует.

Ранее в пределах Минской области P. trichoides отмечался только в Крупском и Любанском районах [19]. 
Семейство Сытевые - Cyperaceae Juss.

Bolboschoenus planiculmis (F. W. Schmidt) T. V. Egorova - Клубнекамыш плоскостебельный

Минская обл., Узденский р-н, Ю-3 окрестности д. Лоша, С-В часть вдхр. Лошанское. К. С.


глубина 0,05-0,1 м, грунт песчаный, вода стоячая, затенение отсутствует. В составе фитоценоза с доминированием Leersia oryzoides (L.) Sw.

Это второе достоверно известное местонахождение B. planiculmis в Минской области [20].

Семейство Мятликовые (Злаки) - Pоасеае Barnhart (Gramineae Juss.)

Catabrosa aquatica (L.) P. Вeauv. - Поручейница водяная

Гродненская обл., Свислочский р-н, 1,3 км к Ю от д. Гринки 1, берег р. Колонна. 5256'26,38" с. ш., $24^{\circ} 7^{\prime} 10,03^{\prime \prime}$ в. д. К. С., И. С. 22.07.17. Площадь сообщества - 15 м².

Глубина 0,2 м, грунт мелкопесчаный, скорость течения высокая, затенение отсутствует. В структуре фитоценоза поручейница является доминантом, произрастает совместно с Berula erecta (Huds.) Coville, Lemna gibba L., L. minor L., Glyceria fluitans (L.) R. Br., G. maxima (Hartm.) Holmb.

Вид недавно также отмечался в реке Крапивница, впадающей в Колонну ближе к ее верховью [21].

\section{Glyceria lithuanica (Gorski) Gorski - Манник литовский}

Минская обл., Дзержинский р-н, окрестность д. Александрова, смешанный заболоченный лес с осиной, черной ольхой, березой, елью. Изредка на площади 10×20 м. Д. М. 13.06.15.

Для Дзержинского района этот охраняемый вид ранее не указывался.

Zizania palustris L. - Цицания болотная

Минская обл., Солигорский р-н, г. Солигорск, на мелководье Солигорского водохранилища. Изредка. Д. М. 27.08.15.

Семейство Роголистниковые - Ceratophyllaceae Gray

Ceratophyllum submersum L. - Роголистник подводный, или погруженный

Минская обл., Копыльский р-н, вдхр. Краснослободское, прибрежная часть акватории. К. С. 02.07.17. Единичные особи, редко. Глубина 0,5 м, грунт торфянисто-песчаный, затенение до $30 \%$.

Семейство Лютиковые - Ranunculaceae Juss.

Ranunculus kauffmannii Clerc. (Batrachium kaufmannii (Clerc) V. Krecz.) - Водяной лютик Кауфмана, или Шелковник Кауфмана

Минская обл., Вилейский р-н, 2,4 км к С от д. Журихи, р. Ментынь (вблизи моста). 54³8'45,03" с. ш., $26^{\circ} 54^{\prime} 45,51^{\prime \prime}$ в. д. К. С. 14.07.13. Численность популяции 21 экз $/ \mathrm{M}^{2}$; площадь, занимаемая метапопуляцией, 1,5 м². Глубина 0,15 м, грунт песчано-каменистый, скорость течения средняя, затенение отсутствует.

Минская обл., Столбцовский р-н, д. Рубежевичи, р. Сула (вблизи моста). 5341'24,94" с. ш., $26^{\circ} 51^{\prime} 27,25^{\prime \prime}$ в. д. К. С. 05.07.17. Численность популяции 16 экз $/ \mathrm{M}^{2}$; площадь, занимаемая метапопуляцией, 11 м². Глубина 0,2 м, грунт песчано-каменистый, скорость течения высокая, затенение 80 \%. Образует сообщество асc. Fontinali-Batrachietum kaufmannii A. Bobrov, 2001.

Семейство Мареновые - Rubiaceae Juss.

Galium trifidum L. - Подмаренник трехнадрезный

Минская обл., Дзержинский р-н, окрестность д. Мостище, южный берег оз. Бездонка. Д. М. 2.08.14. На сплавинах у берега. Изредка на площади $2 \times 5$ м.

Семейство Пузырчатковые - Lentibulariaceae Rich.

Utricularia minor L. - Пузырчатка малая

Гродненская обл., Свислочский р-н, 2,5 км к Ю-3 от д. Тереховичи. Лесной водоем с заболоченными берегами. $52^{\circ} 52^{\prime} 33,34^{\prime \prime}$ с. ш., $24^{\circ} 29^{\prime} 8,44^{\prime \prime}$ в. д. К. С., И. С. 23.07.17. В прибрежном заливе внутри сплавины. Часто на площади $2 \mathrm{~m}^{2}$. Глубина 0,2 м, вода стоячая, затенения нет.

Семейство Астровые (Сложноцветные) - Asteraceae Bercht. et J. Presl (Compositae Giseke)

Petasites spurius (Retz.) Rchb. - Белокопытник ложный

Редкий в Минской области вид, который ранее был известен только в нижнем течении р. Неман. 
Минская обл., Вилейский р-н, окрестность д. Ковали, берег Вилейского водохранилища, Сырые закустаренные пески у берега. Часто на площади 10×20 м. Д. М. 07.09.16. Цветущие растения доставлены нам из данного локалитета в 2015 г. старшим преподавателем кафедры зоологии БГУ А. В. Балашем.

Семейство Сельдереевые (Зонтичные) - Apiaceae Lindl. (Umbelliferae Juss.)

Berula erecta (Huds.) Coville - Берула прямая

Минская обл., Копыльский р-н:

1) д. Луговая, р. Барановка. К. С. 03.07.17. Единичные особи, редко на 200-метровом участке реки. Берег реки, грунт песчаный, затенение до $15 \%$. В сообществе acc. Phalaridetum arundinaceae Libbert, 1931;

2) д. Перевоз, р. Лоша (вблизи моста). К. С. 03.07.17. Мелкие куртины, редко на 300-метровом участке реки. Глубина 0,5 м, грунт илисто-песчаный, затенение отсутствует. В сообществе с доминированием Rorippa amphibia (L.) Besser;

3) д. Песочное, р. Неман (вблизи моста). К. С. 03.07.17. Единичные особи, редко на 200-метровом участке реки. Берег реки, грунт песчаный, затенение до $25 \%$.

Брестская обл., Каменецкий р-н:


К. С., И. С. 20.07.17. Единичные особи, редко. Глубина 0,3 м, грунт илисто-песчаный, течение медленное, затенение отсутствует. По краю фитоценоза ассоциации Phalaridetum arundinaceae W. Koch ex Libb., 1931;

2) 0,5 км к С-3 от д. Голый Борок, р. Лесная. $52^{\circ} 25^{\prime} 38,65^{\prime \prime}$ с. ш., $23^{\circ} 50^{\prime} 56,72^{\prime \prime}$ в. д. К. С., И. С. 19.07.17. Площадь, занимаемая ценопопуляциями, 1-10 м². Распространена (на километровом отрезке реки) вдоль берегов, в основном мелкими куртинами. Сообщества acc. Beruletum erecta в данном локалитете редки и граничат с ценозами асc. Potamogetono-Nupharetum luteae Müller et Görs, 1960, acc. Phragmitetum communis (Gams, 1927) Schmale, 1939;

3) 0,5 км к Ю-В от д. Белая, р. Белая. $52^{\circ} 34^{\prime} 43,94^{\prime \prime}$ с. ш., $23^{\circ} 44^{\prime} 12,53$ " в. д. К. С., И. С. 21.07.17. Единичные особи, редко. Глубина 0,65 м, грунт песчаный, скорость течения высокая, затенение до 50 \% (от Alnus glutinosa (L.) Gaertn.). Фитоценозы асc. Beruletum erecta здесь формируются редко (занимают площадь до $8 \mathrm{~m}^{2}$ ), контактируют с сообществами acc. Phragmitetum communis (Gams, 1927) Schmale, 1939;

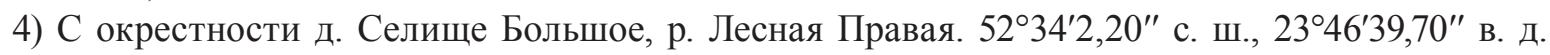
К. С., И. С. 20.07.17. Единичные особи, редко. Глубина 0,4 м, грунт мелкопесчаный, течение медленное, затенение отсутствует. В прибрежной зоне акватории, по краям сообщества acc. Sagittario-Sparganietum emersi Tüxen, 1953;

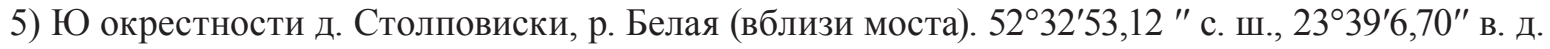
К. С., И. С. 18.07.17. Единичные особи и группы из 2-5 растений, редко. Глубина 1,2 м, грунт илисто-песчаный, течение медленное, затенение практически отсутствует. В сообществе acc. Potamogetono-Nupharetum luteae;

6) окрестность д. Каменюки, Каменюкский с/с, у моста через р. Лесная Правая. Д. М. 28.06.1999. $\sim 145$ м над уровнем моря. № 665. В воде и на мелководье реки. Довольно часто.

Гродненская обл., Свислочский р-н:

1) 1,5 км к С от д. Большие Михалки, р. Лошанка (вблизи моста). $52^{\circ} 58^{\prime} 19,18^{\prime \prime}$ с. ш., $24^{\circ} 12^{\prime} 15,68^{\prime \prime}$ в. д. К. С., И. С. 22.07.17. Площадь, занимаемая метапопуляциями, 0,5-50 м². Глубина 0,25 м, грунт мелкопесчаный, скорость течения высокая, затенение отсутствует. Фитоценозы, образованные Berula erecta (ассоциация Beruletum erectae Roll 1938), произрастают по обоим берегам реки (ширина полос $0,5-1$ м), а также в виде небольших, повторяющихся пятен в центре русла;

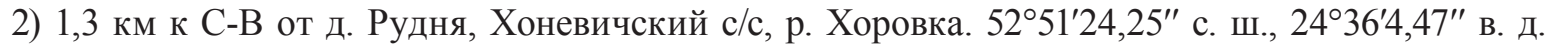
К. С., И. С. 23.07.17. Площадь ценопопуляций - 0,5-20 м². Глубина 0,6 м, грунт крупно-песчаный, скорость течения высокая, затенение от 5 до 45 \% (от Alnus glutinosa (L.) Gaertn.). Фитоценозы acc. Beruletum erecta размещаются по обоим берегам реки пятнами, часто; 


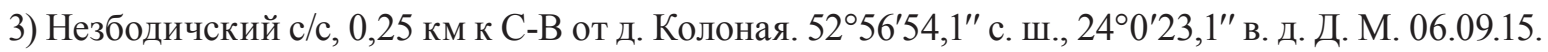
$\sim 155$ м над уровнем моря. № 2807. На мелководье и по берегам р. Колонна, у пересечения с автодорогой Доброволя-Свислочь. Заросли на площади $40 \mathrm{~m}^{2}(2 \times 20 \mathrm{~m})$;

4) Добровольский с/с, Ю-3 окраина д. Доброволя. $52^{\circ} 54^{\prime} 15,4$ " с. ш., $24^{\circ} 0^{\prime} 59,5^{\prime \prime}$ в. д. Д. М. 06.09.15. $~ 150$ м над уровнем моря. № 2809. На мелководье и по берегам р. Пчелка, у пересечения с автодорогой Доброволя-Тиховоля. Часто на площади $120 \mathrm{~m}^{2}(2 \times 60 \mathrm{~m})$;

5) Добровольский с/с, 1 км к С-В от д. Бровск. 5252'23,62" с. ш., 2359'24,16" в. д. Д. М. 06.09.15. $\sim 150$ м над уровнем моря. № 2819. На мелководье и по берегам р. Нарев (русло и рукав реки), у пересечения с автодорогой Доброволя-Тиховоля. Часто на площади $200 \mathrm{~m}^{2}$;

6) Добровольский с/с, 0,25 км к С-В от д. Немержа 5250'27,7" с. ш., 242'12,5 " в. д. Д. М. 06.09.15. 155 м над уровнем моря. № 2832. На мелководье и по берегам р. Нарев, у пересечения с автодорогой Тиховоля-Рудня. Изредка на площади 15 м². $^{2}$

К 2016 г. было известно более 10 местонахождений этого вида в пуще, однако детально распространение здесь берулы прямой не изучалось. Проведенные нами исследования встречаемости Berula erecta в пределах Национального парка показали практически непрерывное (в основном небольшое обилие отдельных особей или микрогрупп) ее распространение преимущественно в прибрежных биотопах в следующих пунктах:

1) участок р. Лесная протяженностью около 2 км - от моста в 0,5 км к С-3 от д. Голый Борок до д. Жданки;

2) участок р. Белая протяженностью около 1,5 км (от моста в Ю-В окрестности д. Белая до устья);

3) участок р. Колонна протяженностью 0,5 км вниз по течению от моста в Ю окрестности д. Гринки-1;

4) участок р. Лошанка протяженностью 0,5 км вниз по течению от моста в С-В окрестности д. Большие Михалки;

5) участок р. Хоровка протяженностью 1,2 км вверх по течению от моста в Ю окрестности д. Борисики.

Большинство мест произрастания берулы прямой сосредоточены в северной, северо-западной и юго-западной частях Национального парка, где наиболее широко представлены естественные, минимально антропогенно измененные элементы гидрографической сети, в том числе крупные реки.

Conioselinum tataricum Hoffm. - Гирчовник татарский, или влагалищный

Минская обл., Минский р-н, окрестность д. Рогово, берег р. Гуйка. Изредка. Д. М. 28.05.07.

Для Минского района этот охраняемый вид ранее не указывался.

Заключение. В результате проведенных исследований выявлено 75 локалитетов 20 видов водных и заходящих в воду береговых растений, охраняемых законом в Республике Беларусь (из которых 7 видов включены в основной список Красной книги, 5 видов - в список профилактической охраны) и 8 видов (а также 1 гибрид) редких для флоры республики растений водных объектов. Местонахождения Nuphar pumila (Timm) DC., Ranunculus kauffmannii Clerc., Najas major All., Berula erecta, Glyceria lithuanica (Gorski) Gorski, Conioselinum tataricum Hoffm., обнаруженные на территории Минской области, отсутствуют в 4-м издании Красной книги Беларуси. Новыми для флоры НП «Беловежская пуща» являются 5 видов водных растений. Полученная информация о местонахождениях охраняемых видов водных растений может быть использована для организации мониторинга их популяций, составления соответствующих охранных паспортов и охранных обязательств.

Благодарности. Выражаем благодарность ведущему научному сотруднику Института экспериментальной ботаники им. В. Ф. Купревича НАН Беларуси, доктору биологических наук И. М. Степановичу за помощь в проведении полевых работ на территории НП «Беловежская пуща».
Acknowledgements. We express our gratitude to the leading scientist of the V. F. Kuprevich Institute of Experimental Botany of the National Academy of Sciences of Belarus, Doctor of Biological Sciences I. M. Stepanovich for assistance in conducting field works in the territory of NP "Belovezhskaya Pushcha". 


\section{Список использованных источников}

1. Дубына, Д. В. Макрофиты - индикаторы изменений природной среды / Д. В. Дубына, С. М. Стойко, К. М. Сытник. - Киев : Наук. думка, 1993. - 432 с.

2. Катанская, В. М. Высшая водная растительность континентальных водоемов СССР. Методы изучения/ В. М. Катанская. - Л. : Наука. Ленингр. отд-ние, 1981. - 187 с.

3. Власов, Б. П. Использование высших водных растений для оценки и контроля за состоянием водной среды : метод. рекомендации / Б. П. Власов, Г. С. Гигевич. - Минск : БГУ, 2002. - 84 с.

4. An update of the Angiosperm Phylogeny Group classification for the orders and families of flowering plants: APG IV / M. W. Chase [et al.] // Bot. J. Linn. Soc. - 2016. - Vol. 181, N 1. - P. 1-20. https://doi.org/10.1111/boj.12385

5. Флора Восточной Европы / Рос. акад. наук, Ботан. ин-т им. В. Л. Комарова ; под ред. Н. Н. Цвелева [и др.]. СПб. : Мир и семья ; Изд-во С.-Петерб. гос. хим.-фармацевт. акад., 2001. - Т. 10. - 670 с.

6. Флора Восточной Европы / Рос. акад. наук, Ботан. ин-т им. В. Л. Комарова ; под ред. Н. Н. Цвелева. - М. ; СПб. : КМК, 2004. - Т. 11. - 534 c.

7. Flora of North America: North of Mexico / Flora of North America editorial comm. - New York : Oxford Univ. Press, 2000. - Vol. 22 : Magnoliophyta: Alismatidae, Arecidae, Commelinidae (in part), and Zingiberidae. - 384 p.

8. Wiegleb, G. A taxonomic account of Ranunculus section Batrachium (Ranunculaceae) / G. Wiegleb, A. A. Bobrov, J. Zalewska-Gałosz // Phytotaxa. - 2017. - Vol. 319, N 1. - P. 1-55. https://doi.org/10.11646/phytotaxa.319.1.1

9. Kaplan, Z. Potamogeton taxa proposed by J. F. Wolfgang and his collaborators / Z. Kaplan, J. Zalewska-Gałosz // Taxon. - Vol. 53, N 4. - 2004. - P. 1033-1041. https://doi.org/10.2307/4135570

10. Тетерюк, Б. Ю. Водная и прибрежно-водная растительность озера Ямозеро (Республика Коми) / Б. Ю. Тетерюк // Растительность России. - 2011. - № 19.- С. 101-116.

11. Водная растительность Южного Урала (Республика Башкортостан). II. Класс Potametea / Я. М. Голованов [и др.] // Растительность России. - 2015. - № 27. - С. 40-77.

12. Тетерюк, Б. Ю. Синтаксономический обзор растительности водоемов бассейна р. Вычегда (Европейский северо-восток России) / Б. Ю. Тетерюк // Известия Коми науч. центра Урал. отд-ния Рос. акад. наук. - 2017. - Вып. 29, № 1.- С. $18-27$.

13. Киприянова, Л. М. Водная и прибрежно-водная растительность рек Чулым и Каргат (Западная Сибирь) / Л. М. Киприянова // Растительность России. - 2013. - № 22. - С. 62-77.

14. Дубына, Д. В. Синтаксономическое разнообразие растительности устьевой области Днепра. IV. Класс Роtametea Klika in Klika et Novák 1941 / Д. В. Дубына, Т. П. Дзюба // Растительность России. - 2010. - № 16. - С. 3-26.

15. Папченков, В. Г. Основные гидроботанические понятия и сопутствующие им термины: проект / В. Г. Папченков, А. В. Щербаков, А. Г. Лапиров. - Рязань : Сервис, 2003. - 21 с.

16. First record of Nymphaea $\times$ marliacea Lat.-Marl. "Rosea" in the Iberian Peninsula: identification based on morphological features and molecular techniques / E. D. Dana [et al.] // Bouteloua. - 2017. - Vol. 28. - P. 132-139.

17. Адвентивная флора Москвы и Московской области / С. Р. Майоров [и др.]. - М. : КМК, 2012. - 412 с.

18. Джус, М. А. Ряска турионообразующая (Lemna turionifera Landolt, Lemnaceae) - новый вид для флоры Беларуси и Национального парка «Нарочанский» / М. А. Джус // Особо охраняемые природные территории Беларуси : исследования : сб. науч. ст. / редкол. : В. С. Ивкович (отв. ред.) [и др.]. - Минск, 2011. - Вып. 6. - С. 65-80.

19. Флора Беларуси. Сосудистые растения : в 6 т. / Нац. акад. наук Беларуси, Ин-т эксперим. ботаники им. В. Ф. Купревича ; под общ. ред. В. И. Парфенова. - Минск : Беларус. навука, 2009. - Т. 2 : Liliopsida (Acoraceae, Alismataceae, Araceae, Butomaceae, Commelinaceae, Hydrocharitaceae, Juncaginaceae, Lemnaceae, Najadaceae, Poaceae, Potamogetonaceae, Scheuchzeriaceae, Sparganiaceae, Typhaceae, Zannichelliaceae) / Д. И. Третьяков [и др.]. - 447 с.

20. Флора Беларуси. Сосудистые растения : в 6 т. / Нац. акад. наук Беларуси, Ин-т эксперим. ботаники им. В. Ф. Купревича ; под общ. ред. В. И. Парфенова. - Минск : Беларус. навука, 2009. - Т. 3 : Liliopsida (Agavaceae, Alliaceae, Amaryllidaceae, Asparagaceae, Asphodelaceae, Cannaceae, Colchicaceae, Convallariaceae, Cyperaceae, Dioscoreaceae, Iridaceae, Ixioliridaceae, Hemerocallidaceae, Hostaceae, Hyacinthaceae, Juncaceae, Liliaceaem Melanthiaceae, Ophiogonaceae, Orchidaceae, Pontederiaceae, Tofieldiaceae, Trilliaceae) / Д. В. Дубовик [и др.]. - 2017. - 571 с.

21. Находки некоторых редких аборигенных и адвентивных видов сосудистых растений в Беларуси / Д. В. Дубовик [и др.] // Ботаника (исследования) : сб. науч. тр. / Ин-т эксперим. ботаники НАН Беларуси. - Минск, 2016. Вып. 45. - С. 404-415.

\section{References}

1. Dubyna D. V., Stoiko S. M., Sytnik K. M. Macrophytes indicators of environmental changes. Kiev, Naukova dumka Publ., 1993. 432 p. (in Russian).

2. Katanskaya V. M. Higher aquatic vegetation of the continental water bodies of the USSR. Methods of investigation. Leningrad, Nauka (Leningradskoe otdelenie) Publ., 1981. 187 p. (in Russian).

3. Vlasov B. P., Gigevich G. S. Use of higher aquatic plants for assessment and control of the state of the aquatic environment: methodological recommendations. Minsk, Publishing house of the Belarusian State University, 2002. 84 p. (in Russian).

4. Chase M. W., Christenhusz M. J. M., Fay M. F., Byng J. W., Judd W. S., Soltis D. E., Mabberley D. J., Sennikov A. N., Soltis P. S., Stevens P. F. An update of the Angiosperm Phylogeny Group classification for the orders and families of flowering plants: APG IV. Botanical Journal of the Linnean Society, 2016, vol. 181, no. 1, pp. 1-20. https://doi.org/10.1111/boj.12385 
5. Gel'tman D. V., Grudzinskaya I. A., Egorova T. V., Sokolova I. V., Tsvelev N. N. (eds.). Flora Europae orientalis. Vol. 10. Saint Petersburg, Mir i Sem'ya Publ., Publishing house of the Saint Petersburg State Chemical and Pharmaceutical Academy, 2001. 670 p. (in Russian).

6. Tsvelev N. N. (ed.). Flora Europae orientalis. Vol. 11. Moscow, Saint Petersburg, KMK Publ., 2004. 534 p. (in Russian).

7. Flora of North America: North of Mexico. Vol. 22. Magnoliophyta: Alismatidae, Arecidae, Commelinidae (in part), and Zingiberidae. New York, Oxford University Press, 2000. 384 p.

8. Wiegleb G., Bobrov A. A., Zalewska-Gałosz J. A taxonomic account of Ranunculus section Batrachium (Ranunculaceae). Phytotaxa, 2017, vol. 319, no. 1, pp. 1-55. https://doi.org/10.11646/phytotaxa.319.1.1

9. Kaplan Z., Zalewska-Gałosz J. Potamogeton taxa proposed by J. F. Wolfgang and his collaborators. Taxon, 2004, vol. 53, no. 4, pp. 1033-1041. https://doi.org/10.2307/4135570

10. Teteryuk B. Yu. Aquatic and helophytic vegetation of the Yamozero Lake (The Komi Republic). Rastitel'nost' Rossii [Vegetation of Russia], 2011, no. 19, pp. 101-116 (in Russian).

11. Golovanov Ya. M., Yamalov S. M., Baktybaeva Z. B., Petrov S. S. Aquatic vegetation of the South Urals (Bashkortostan Republic). II. Class Potametea. Rastitel'nost'Rossii [Vegetation of Russia], 2015, no. 27, pp. 40-77 (in Russian).

12. Teteryuk B. Yu. Syntaxonomical overview of vegetation of water bodies of the Vychegda river basin (European North-East of Russia). Izvestiya Komi nauchnogo tsentra Ural'skogo otdeleniya Rossiiskoi akademii nauk [Proceedings of the Komi Science Centre of the Ural Division of the Russian Academy of Sciences], 2017, no. 1, vol. 29, pp. 18-27 (in Russian).

13. Kipriyanova L. M. Aquatic and semiaquatic vegetation of the Chulym and Kargat rivers (West Siberia). Rastitel'nost' Rossii [Vegetation of Russia], 2013, no. 22, pp. 62-77 (in Russian).

14. Dubyna D. V., Dzyuba T. P. Syntaxonomical diversity of vegetation of the Dnieper mouth region. IV. Class Potametea Klika in Klika et Novák 1941. Rastitel'nost' Rossii [Vegetation of Russia], 2010, no. 16, pp. 3-26 (in Russian).

15. Papchenkov V. G., Shcherbakov A. V., Lapirov A. G. Basic hydrobotanical concepts and associated terms: project. Ryazan', Servis Publ., 2003. 21 p. (in Russian).

16. Dana E. D., Verloove F., Guillot Ortiz D., Rodríguez-Marzal J. L., Paredes-Carretero F., Juan Bañón J. L., Esteban E., García-de-Lomas J. First record of Nymphaea $\times$ marliacea Lat.-Marl. "Rosea" in the Iberian Peninsula: identification based on morphological features and molecular techniques. Bouteloua, 2017, vol. 28, pp. 132-139.

17. Maiorov S. R., Bochkin V. D., Nasimovich Yu. A., Shcherbakov A. V. Adventive flora of Moscow and Moscow region. Moscow, KMK Publ., 2012. 412 p. (in Russian).

18. Dzhus M. A. Red duckweed (Lemna turionifera Landolt, Lemnaceae) - new species to Belarus and Narochanskiy National Park]. Osobo okhranyaemye prirodnye territorii Belarusi: issledovaniya: sbornik nauchnykh statei [Specially Protected Natural Territories of Belarus: Research: a collection of scientific articles]. Minsk, 2011, iss. 6, pp. 65-80 (in Russian).

19. Parfenov V. I. (ed.). Flora of Belarus. Vascular plants. Vol. 2. Liliopsida (Acoraceae, Alismataceae, Araceae, Butomaceae, Commelinaceae, Hydrocharitaceae, Juncaginaceae, Lemnaceae, Najadaceae, Poaceae, Potamogetonaceae, Scheuchzeriaceae, Sparganiaceae, Typhaceae, Zannichelliaceae). Minsk, Belaruskaya navuka Publ., 2013. 447 p. (in Russian).

20. Parfenov V. I. (ed.). Flora of Belarus. Vascular plants. Vol. 3. Liliopsida (Agavaceae, Alliaceae, Amaryllidaceae, Asparagaceae, Asphodelaceae, Cannaceae, Colchicaceae, Convallariaceae, Cyperaceae, Dioscoreaceae, Iridaceae, Ixioliridaceae, Hemerocallidaceae, Hostaceae, Hyacinthaceae, Juncaceae, Liliaceaem Melanthiaceae, Ophiogonaceae, Orchidaceae, Pontederiaceae, Tofieldiaceae, Trilliaceae). Minsk, Belaruskaya navuka Publ., 2017. 571 p. (in Russian).

21. Dubovik D. V., Savchuk S. S., Skuratovich A. N., Lebed'ko V. N. New data to distribution of some rare native and adventive species of vascular plants of flora of Belarus. Botanika (issledovaniya): sbornik nauchnykh trudov [Botany (research): a collection of scientific papers]. Minsk, 2016, vol. 45, pp. 404-415 (in Russian).

\section{Информация об авторах}

Савицкая Карина Леонидовна - мл. науч. сотрудник. Институт экспериментальной ботаники имени В. Ф. Купревича НАН Беларуси (ул. Академическая, 27, 220072, г. Минск, Республика Беларусь). E-mail: karina_savv@ mail.ru

Джус Максим Анатольевич - канд. биол. наук, доцент. Белорусский государственный университет (пр-т Независимости, 4, 220030, г. Минск, Республика Беларусь). E-mail: dzhus_maxim@mail.ru

\section{Information about the authors}

Karina L. Savitskaya - Junior researcher. V. F. Kuprevich Institute of Experimental Botany of the National Academy of Sciences of Belarus (27, Akademicheskaya Str., 220072, Minsk, Republic of Belarus). E-mail: karina_savv@ mail.ru

Maxim A. Dzhus - Ph. D. (Biol.), Assistant Professor. Belarusian State University (4, Nezavisimosti Ave., 220030, Minsk, Republic of Belarus). E-mail: dzhus_maxim@mail.ru 